\title{
ReSEARChArticle
}

\section{Effect of zinc and boron on growth of brinjal (Solanum melongena L.)}

\author{
MAHESH M. SOLANKI, MANJUSHA S. SOLANKI, GAJANAN THAKARE, PALLAVI D. JOGI \\ AND DEEPAK R. SAPKAL
}

\section{SUMMARY}

A micronutrient is the essential element for plant growth and development. Present study amied to exploer in detail the effect of zinc and boron on growth, yield and quality of brinjal (Solanum melongena L.). The experiment consisted of 9 treatments laid out Completely Randomized Design with three replications. The individual treatment of $5 \mathrm{mg}$ zinc, $10 \mathrm{mg}$ zinc, $5 \mathrm{mg}$ boron and $10 \mathrm{mg}$ boron and treatment combinations $5 \mathrm{mg} \mathrm{Zn}+5 \mathrm{mg} \mathrm{B}, 5 \mathrm{mg} \mathrm{Zn}+10 \mathrm{mg} \mathrm{B}, 10 \mathrm{mg} \mathrm{Zn}+5 \mathrm{mg} \mathrm{B}$ and $10 \mathrm{mg} \mathrm{Zn}+10 \mathrm{mg} B$ per kg soil was given in brinjal pots, the growth parameters like plant height, number of leaves, number of branches, number of flowers and yield parameters like maximum number of fruits per plant was obtained in brinjal influenced by combination of treatments $\mathrm{T}_{8}(10 \mathrm{mg} \mathrm{Zn}+10 \mathrm{mg} \mathrm{B})$ and was significantly superior at 5 per cent over rest of the treatments.

Key Words : Boron, Zinc, Solanum melongena L., Quality

How to cite this article : Solanki, Mahesh M., Solanki, Manjusha S., Thakare, Gajanan, Jogi, Pallavi D. and Sapkal, Deepak R. (2017). Effect of zinc and boron on growth of brinjal (Solanum melongena L.). Internat. J. Plant Sci., 12 (2): 160-163, DOI: 10.15740/HAS/IJPS/12.2/160-163.

Article chronicle : Received : 24.03.2017; Revised : 05.05.2017; Accepted : 23.05.2017

\section{MEMBERS OF THE RESEARCH FORUM}

Author to be contacted :

MANJUSHA S. SOLANKI, Department of Biological Sciences, Allahabad School of Agriculture, Sam Higginbottom Institute of Agricutlure, Technology and Sciences, ALLAHABAD (U.P.) INDIA

Email : maheshraj720@gmail.com

Address of the Co-authors:

MAHESH M. SOLANKI, GAJANAN THAKARE, PALLAVI D. JOGI

AND DEEPAK R. SAPKAL, Department of Biological Sciences, Allahabad School of Agriculture, Sam Higginbottom Institute of Agricutlure, Technology and Sciences, ALLAHABAD (U.P.) INDIA 